\author{
Asian Journal of \\ Medical and Biological Research \\ ISSN 2411-4472 (Print) 2412-5571 (Online) \\ www.ebupress.com/journal/ajmbr
}

\title{
Article \\ Effect of different dietary protein level on growth, production and survivability of threatened Mystus cavasius (Hamilton-Buchanan 1822) in pond habitat
}

\author{
Md. Abdus Samad ${ }^{1 *}$, Esmot Jahan Alice ${ }^{1}$ and Dipankar Pal ${ }^{2}$ \\ ${ }^{1}$ Department of Fisheries, University of Rajshahi, Rajshahi-6205, Bangladesh \\ ${ }^{2}$ Upazila Fisheries Officer, Department of Fisheries (DOF), Lalmonirhat, Bangladesh \\ *Corresponding author: Md. Abdus Samad, Department of Fisheries, University of Rajshahi, Rajshahi-6205, \\ Bangladesh. Phone: +8801711481523; E-mail: samad1413@yahoo.com
}

Received: 01 November 2020/Accepted: 23 December 2020/ Published: 31 December 2020

\begin{abstract}
A study was undertaken to determine the effect of different dietary protein levels on growth, survival and production of Mystus cavasius (Hamilton-Buchanan 1822) with three experimental diets containing 29\%, $32 \%$ and $35 \%$ protein level applied simultaneously to three treatments $\mathrm{T}_{1}, \mathrm{~T}_{2}$ and $\mathrm{T}_{3}$ respectively each with three replications. The stocking density $(1,11,150 / \mathrm{ha})$, initial weight $(3.00 \pm 00 \mathrm{~g})$ and length $(2.00 \pm 0.00 \mathrm{~cm})$ of fish were same for all the treatments. No significant $(\mathrm{P}>0.05)$ difference was found for the mean values of water quality parameters. A suitable range of water quality parameters were recorded with the environment of experimental ponds. In terms of growth, production and survival, relatively highest performance was found in the treatment $\mathrm{T}_{3}$. After 180 days of rearing, average weight gain was $29.16 \pm 0.43 \mathrm{~g}, 31.17 \pm 0.30 \mathrm{~g}$ and $37.44 \pm 0.32 \mathrm{~g}$ with the above three different feeds, respectively. The average daily gain (ADG) and specific growth rate (SGR) of all treatments showed significant difference $(\mathrm{P}<0.05)$ and the highest value $(0.21 \pm 0.04$ and $1.43 \pm 0.01 \%$ ) was found with the $35 \%$ dietary protein level containing diet. Feed conversion ratio (FCR) improved with increase of dietary protein. The findings of FCR were $2.97 \pm 0.02$ at $29 \%$ protein level $\left(\mathrm{T}_{1}\right)$, $2.64 \pm 0.02$ at $32 \%$ protein level $\left(\mathrm{T}_{2}\right)$ and $2.20 \pm 0.01$ at $35 \%$ protein level $\left(\mathrm{T}_{3}\right)$. The results of protein efficiency ratio (PER) values were fairly similar of $1.17 \pm 0.02$ and $1.18 \pm 0.01$ for $29 \%$ and $32 \%$ protein level containing diets respectively indicating low efficiency and the highest efficiency $(1.30 \pm 0.01)$ was found with $35 \%$ protein level. The findings of condition factor in different treatments for Mystus cavasius were not significantly $(\mathrm{P}>0.05)$ varied with the treatments. Calculated values of condition factor were $1.04 \pm 0.00,1.03 \pm 0.03$ and $1.09 \pm 0.05$ in treatment $T_{1}, T_{2}$ and treatment $T_{3}$, respectively. In pond culture, the performance of treatment $T_{3}$ was found to be better than the treatment $T_{1}$ and $T_{2}$. The production was of $3616 \pm 16.74 \mathrm{~kg} / \mathrm{ha}$ in $T_{3}$ during the culture period of six months. The best cost benefit ratio (CBR) value (1.98 \pm 0.02$)$ was also found with treatment $\mathrm{T}_{3}$. The $35 \%$ dietary protein level with treatment $\mathrm{T}_{3}$ resulted in best growth performance and was probably adequate to meet the dietary protein needs of Mystus cavasius (Hamilton-Buchanan, 1822).
\end{abstract}

Keywords: Mystus cavasius; dietary protein; survival; production

\section{Introduction}

Mystus cavasius (Hamilton-Buchanan, 1822) is a catfish under family Bagridae of order Siluriformes. According to IUCN 2015, Mystus cavasius is enlisted as near threatened catfish. It is commonly known as Gangetic Mystus which has been reported to be distributed in India, Bangladesh, Pakistan, Nepal, Sri Lanka, Thailand and Myanmar. The fish is usually found in fresh water and is mostly available in rivers (both fast flowing and slow flowing), canals, beels, ponds, ditches and inundated fields.

It has been found that this fish has high nutritive value. Chemically the flesh of $M$. cavasius contains $78.99 \mathrm{~g}$ moisture, $16.16 \mathrm{~g}$ protein(muscle), $2.26 \mathrm{~g}$ fat, $4.77 \mathrm{~g}$ ash, protein $13.81 \mathrm{~g}$, and gross energy 4.16 (Hossain et al. 1999). This type of composition is not found in any other fishes like Catla catla, Labeo rohita, Cirrhinus mrigala etc. This fish has a great consumer preference with its delicious taste and therefore have a great demand 
and high price in the market also. Considering the top ten choices by all categories of consumers, Mystus cavasius holds second place with $67.50 \%$ consumer preference among the recorded small indigenous of the Padma river (Samad et al., 2010).

In Bangladesh different private and Govt. fish seed firms have developed seed production technology through artificial propagation This species is reported quite favorable under standard conditions of carp farming (Hossain et al., 1998) but their monoculture has not yet been available in the country (Kohinoor et al., 2004).

The growth of fish biomass under intensive mono-culture depends upon various factors especially on feed. The most noticeable problem facing fish culturist is the need to obtain a balance between a rapid fish growth and optimum use of the supplied feed. In aquaculture nutrition is one of the most critical factors because feed represent $40-50 \%$ of production cost. (Craig and Helfrish, 2002).

Protein plays a significant role in providing fish growth. Fish consume protein to obtain the essential and nonessential amino acids, which are necessary for muscle formation and enzymatic function and in part provide energy for maintenance (Yang et al., 2002). 65-70\% of the dry weight of fish muscle comprises with protein which is the most important and basal constituent among all the nutrients required by fish for growth and maintenance, and is also metabolized as an energy source by fish. (Wilson and Halver, 1986). Insufficient protein in the diet results in a delay of growth and a loss of weight whereas diet with excessive protein contents usually causes energy costs, increased the nitrogenous excretion and reduce the growth of fish. (Monentcham et al., 2009; Tawwab et al., 2010) Any excess is considered wasteful, biologically as well as economically and therefore, it is important to minimize the amount of protein used for energy (NRC, 1993; Deng et al., 2011) .The mixture of ingredients is necessary to contribute a balance of required nutrients. No single ingredients can provide the total nutritive source; therefore, a high-quality food should contain a mixture of animal and plant proteins as well as supplemental vitamins and minerals (Rahman et al., 2013). However, the optimum dietary protein requirements are known to be affected by several factors including the fish species and size, the quality of the protein source, and the amount of non-protein energy in the diet (NRC, 2011).

Therefore, in the present study attempts were taken to investigate the growth performance in different protein level containing feed for Mystus cavasius in pond habitat for domestication as well as conservation of this species.

\section{Materials and Methods}

\subsection{Location and duration of the study}

The experiment was carried out for six months during November 2016 to April 2017, crossing both winter and summer season in three experimental ponds was at Tanore Upzila, Rajshahi All the ponds were well exposed to sunlight.

\subsection{Experimental design}

The experiment was carried out in Tanore, Rajshahi. The experiment was designed (Table 1) for rearing Mystus cavasius in Three treatments (100 decimal and $1.5 \mathrm{~m}$ depth) of each different dietary protein level containing feed, they are 29\%,32\% and 35\% in treatment $\mathrm{T}_{1}, \mathrm{~T}_{2}$, and $\mathrm{T}_{3}$ respectively. To each of the experimental ponds $1,11,150 /$ ha fish seed were released having mean length $2.00 \pm 02 \mathrm{~cm}$ and mean weight $3.00 \pm 01 \mathrm{~g}$ at the initial period.

Table 1. Lay out of the experimental design.

\begin{tabular}{lll}
\hline Treatment & Protein level of feed & Stocking density \\
\hline $\mathrm{T}_{1}$ - Diet 1 & $29 \%$ & $450 /$ decimal \\
\hline $\mathrm{T}_{2}$ - Diet 2 & $32 \%$ & $450 /$ decimal \\
\hline $\mathrm{T}_{3}$ - Diet 3 & $35 \%$ & $450 /$ decimal \\
\hline
\end{tabular}

\subsection{Experimental fish}

Gulsha (Mystus cavasius) fry were used in this experiment. Fish fry were collected from Satata Matsha Hatchery and Fishery, Tarakanda, Mymensingh. All the fish were the same age group having mean weight of $3.00 \pm 0.00 \mathrm{~g}$ with the treatments $\mathrm{T}_{1}, \mathrm{~T}_{2}$ and $\mathrm{T}_{3}$, respectively. Prior to start of the experiment, the Gulsha (Mystus cavasius) fingerlings were acclimatized to the new environment. Then the fish were stocked in the ponds according to the experimental design. 
2.4. Pond preparation and stocking

Aquatic weeds were removed from the ponds manually. Liming was done at a rate of $1-2 \mathrm{~kg} / \mathrm{decimal}$ before seven days of fertilization. All the ponds were fertilized with Cow dung 5-7 kg/dec, urea 100-150 g/dec and TSP $50-75 \mathrm{~g} / \mathrm{dec}$ as basal dose.

One week after basal fertilization all the ponds were stocked with Mystus cavasius having an average length and weight of $2 \mathrm{~cm}$ and $3 \mathrm{~g}$, respectively with stocking density of 450 individuals/ decimal.

\subsection{Preparation of feed and application}

Seven available ingredients which were fish meal, Fish meal, Soyabean meal, Meat and bone meal, Mustard oil cake, Maize bran, Wheat flour, Rice bran used in preparing feed. The proximate composition of feed has been presented to calculate different protein level for Mystus cavasius in Table 2. The inclusion rate of different feed ingredients (Table 3) were calculated using Microsoft excel, 2007.The required quantities of all ingredients mixed with machine (prepared feed) and spread it to the experimental pond surface.

Feeding adjustment was done every two weeks based on a feeding rate from $10 \%$ down to $5 \%$ of the average body weight. The amount of feeds used per treatment was recorded daily.

Table 2. Proximate composition of different feed ingredients.

\begin{tabular}{lllllll}
\hline Ingredients & $\begin{array}{l}\text { Moisture } \\
(\%)\end{array}$ & $\begin{array}{l}\text { Protein }(\% \\
\text { on D.M) }\end{array}$ & $\begin{array}{l}\text { Lipid (\% on } \\
\text { D.M) }\end{array}$ & $\begin{array}{l}\text { Fibre }(\% \text { on } \\
\text { D.M) }\end{array}$ & $\begin{array}{l}\text { Ash (\% on } \\
\text { D.M) }\end{array}$ & $\begin{array}{l}\text { NFE }(\% \text { on } \\
\text { D.M) }\end{array}$ \\
\hline Fish meal & 17.63 & 61.5 & 7.62 & 1.54 & 25.89 & 3.45 \\
\hline Soyabean meal & 14.46 & 44 & 13.44 & 12.12 & 9.73 & 20.71 \\
\hline Meat and bone meal & 9.93 & 48 & 3.90 & 1.12 & 1.60 & 45.38 \\
\hline Mustard oil cake & 10.67 & 31 & 4.43 & 9.71 & 4.93 & 49.93 \\
\hline Maize bran & 11.67 & 13 & 10.45 & 20.85 & 16.40 & 39.3 \\
\hline Wheat flour & 9.14 & 14 & 8.4 & 18.5 & 13.5 & 45.6 \\
\hline Rice bran & 10.32 & 13 & 6.8 & 19.6 & 14.2 & 46.4 \\
\hline
\end{tabular}

NFE calculated as $=100 \%-($ crude protein + crude lipid + crude fiber + ash $)$

Table 3. Inclusion rate of different feed ingredients used in the experiment.

\begin{tabular}{llll}
\hline Ingredients & \multicolumn{2}{c}{ Inclusion rate (\%) in different treatments } \\
\cline { 2 - 4 } & $\mathbf{T}_{\mathbf{1}} \mathbf{( 2 9 \% )}$ & $\mathbf{T}_{\mathbf{2}} \mathbf{( 3 2 \% )}$ & $\mathbf{T}_{\mathbf{3}} \mathbf{( 3 5 \% )}$ \\
\hline Fish meal & 12 & 15 & 20 \\
\hline Soyabean meal & 12 & 15 & 15 \\
\hline Meat and bone meal & 12 & 15 & 15 \\
\hline Mustard oil cake & 15 & 15 & 15 \\
\hline Maize bran & 15 & 13 & 12 \\
\hline Wheat flour & 15 & 12 & 10 \\
\hline Rice bran & 15 & 12 & 10 \\
\hline Binder & 1 & 1 & 2 \\
\hline Vitamin and Mineral & 2 & 2 & 1 \\
\hline
\end{tabular}

\subsection{Water quality monitoring}

Physico-chemical parameters like water temperature $\left({ }^{\circ} \mathrm{C}\right)$, transparency $(\mathrm{cm})$, dissolved oxygen $(\mathrm{mg} / \mathrm{l}), \mathrm{NH}_{3}-\mathrm{N}$ $(\mathrm{mg} / \mathrm{l}), \mathrm{P}^{\mathrm{H}}$ and alkalinity $(\mathrm{mg} / \mathrm{l})$ of each experimental pond were measured fortnightly and data were recorded carefully on sampling dates. A centigrade thermometer was used for temperature recording, Secchi disc for transparency and the chemical parameters were recorded using Hack Kit box (FF2, USA). All the recordings were taken between 9.00 am to $10 \mathrm{am}$.

\subsection{Monitoring of fish growth}

In each month $10 \%$ of the stocked fishes were caught from each pond with the help of a cast net for the study of growth performance of fish. The following parameters were used to evaluate the growth performance of fishes under different treatments- 
2.7.1. Estimation of weight gain

Estimation of weight gain was performed using the following formula,

Weight gain= final weight $(\mathrm{g})-$ initial weight of fish $(\mathrm{g})$

\subsubsection{Average daily gain (ADG)}

Average daily gain was defined by the following formula,

$\mathrm{ADG}=($ Mean final body weight-Mean initial body weight $) /$ Time $\left(\mathrm{T}_{2}-\mathrm{T}_{1}\right)$

\subsubsection{Specific growth rate, $\operatorname{SGR}\left(\% \mathrm{bwd}^{-1}\right)$}

Specific growth rate (SGR) was calculated as the percentage increase in weight per animal per day. $\mathrm{SGR} \%=\left(\mathrm{In} \mathrm{WT}-\ln \mathrm{W}_{1}\right) /(\mathrm{T}-\mathrm{t}) \times 100$.

\subsubsection{Estimation of feed conversion ration (FCR)}

FCR value is one of the most important factor in an aquaculture program. The formula which was used for obtaining FCR is given below-FCR =Dry weight of feed fed $(\mathrm{g}) /$ live weight gain $(\mathrm{g})$.

\subsubsection{Protein efficiency ratio (PER)}

The PER value was found by using the following formula-wet weight gain of fish (g)/ weight of protein fed $(\mathrm{g})$. (Dry feed based).

\subsubsection{Condition Factor $(\mathrm{K})$}

Condition factor is an indicator of the changes in food reserves and therefore an indicator of the general fish condition. Condition factor of the Mystus cavasius was calculated by the following formula suggested by Fulton (1904) as, $\mathrm{K}=\frac{\mathrm{W}}{\mathrm{L}_{3}} \times 100$, Where, $\mathrm{K}=$ condition factor, $\mathrm{W}=$ body weight, $\mathrm{L}=$ body Length

\subsubsection{Estimation of survival rate}

The survival rate of Mystus cavasius for each treatment and replication was estimated at the end of the 180 days. The survival rate was calculated thus,

Survival rate $(\%)=\frac{\text { No. of actual fish survived }}{\text { No. of actual fish stocked }}$

\subsection{Economics}

Simple cost-benefit analysis was followed to study the economics of tilapia monoculture under different treatments for the present study. Data on both fixed and variable costs were recorded to determine the total cost (Tk/ha/6 months). Total return determined from the market price of fish was expressed as $\mathrm{Tk} / \mathrm{ha} / 4$ months. Net benefit calculated by deducting the total return from total cost was expressed as Tk/ ha/6 months. CBR was calculated as follows:

$\mathrm{CBR}=$ Net benefit/total cost.

\subsection{Statistical analysis}

All the collected data were subjected to using one-way analysis of variance (ANOVA) and tested Duncan's New Multiple Range Test (DMRT) to identify significant differences among the mean values. This statistical analysis was performed with the support of the computer software SPSS (Statistical package for social sciences, 16) program (Zar, 1984).

\section{Results}

\subsection{Monitoring water quality parameters}

Water quality parameters were monitored fortnightly. Water temperature varied from $25.01 \pm 0.3^{\circ} \mathrm{C}$ to $26.13 \pm 0.76^{\circ} \mathrm{C}$; Water transparency, $27.64 \pm 0.23$ to $28.79 \pm 0.58 \mathrm{~cm}$; Dissolved oxygen, $5.05 \pm 0.05$ to $5.12 \pm 0.03$ $\mathrm{mg} / 1$; PH, $7.02 \pm 0.11$ to $7.73 \pm 0.02$; CO2, $1.05 \pm 0.18$ to $1.43 \pm 0.08$; Alkalinity, $137.67 \pm 1.53$ to $140.00 \pm 1.00 \mathrm{mg} / 1$ and NH3-N, $0.016 \pm 0.002$ to $0.020 \pm 0.003 \mathrm{mg} / 1$. Significant differences $(\mathrm{P}<0.05)$ were not found among the water quality parameters of the three treatments (Table 4 ). 
Table 4. Variation in the mean values of water quality parameters under different treatments.

\begin{tabular}{lllll}
\hline Treatments parameters & $\mathbf{T}_{\mathbf{1}}$ & $\mathbf{T}_{\mathbf{2}}$ & $\mathbf{T}_{\mathbf{3}}$ & Level of significance at 5\% \\
\hline Temperature $\left({ }^{\circ} \mathrm{C}\right)$ & $26.13 \pm 0.76$ & $25.33 \pm 0.31$ & $25.01 \pm 0.34$ & $\mathrm{NS}$ \\
\hline Transparency $(\mathrm{cm})$ & $28.79 \pm 0.58$ & $27.64 \pm 0.23$ & $28.02 \pm 0.22$ & $\mathrm{NS}$ \\
\hline $\mathrm{DO}(\mathrm{mg} / 1)$ & $5.05 \pm 0.05$ & $5.14 \pm 0.0$ & $5.12 \pm 0.03$ & $\mathrm{NS}$ \\
\hline $\mathrm{P}^{\mathrm{H}}$ & $7.50 \pm 0.10$ & $7.02 \pm 0.11$ & $7.73 \pm 0.02$ & $\mathrm{NS}$ \\
\hline Alkalinity $(\mathrm{mg} / 1)$ & $137.67 \pm 1.53$ & $139.00 \pm 1.00$ & $140.00 \pm 1.00$ & $\mathrm{NS}$ \\
\hline $\mathrm{NH}_{3}-\mathrm{N}(\mathrm{mg} / 1)$ & $0.019 \pm 0.004$ & $0.020 \pm 0.003$ & $0.016 \pm 0.002$ & $\mathrm{NS}$ \\
\hline
\end{tabular}

NS= Not significant

\subsection{Growth performance}

Variations in the mean values of growth parameters under different treatments during the study period are summarized in Table 5. Variations in the monthly values of weight under different treatments during the study period are shown in Figure 1. In most of the cases treatment $T_{3}$ varied significantly $(P>0.05)$ from treatment $T_{1}$ and $T_{2}$. The values of final weight were $32.17 \pm 0.43$ in treatment $T_{1}, 34.98 \pm 0.3$ in treatment $T_{2}$ and $40.44 \pm 0.32 \mathrm{~g}$ in treatment $\mathrm{T}_{3}$. The results of average weight gain were $29.16 \pm 0.43,31.17 \pm 0.30$, and $37.44 \pm 0.32$ in treatment $\mathrm{T}_{1}, \mathrm{~T}_{2}$ and $\mathrm{T}_{3}$ respectively. The average daily gain was found to be ranged from $0.16 \pm 0.01$ to $0.21 \pm 0.04 \mathrm{~g}$. Values of mean SGR were $1.30 \pm 0.03,1.35 \pm 0.05$ and $1.43 \pm 0.01$ in treatment $\mathrm{T}_{1}, \mathrm{~T}_{2}$ and $\mathrm{T}_{3}$ respectively. The mean value of FCR was recorded $2.20 \pm 0.01$ in treatment $\mathrm{T}_{3}, 2.64 \pm 0.02$ in treatment $\mathrm{T}_{2}$, and $2.97 \pm 0.02$ in treatment $T_{1}$. The highest value of PER was $1.30 \pm 0.01$ in treatment $T_{3}$ and the lowest $(1.17 \pm 0.02)$ value was found in Treatment $T_{1}$. The best result $(1.09 \pm 05)$ of condition factor was recorded in treatment $T_{3}$. The results of survival rate were $72.43 \pm 1.20,75.82 \pm 1.15$ and $80.45 \pm 0.87$ in treatment $T_{1}, T_{2}$ and $T_{3}$ respectively. The mean values of production $(\mathrm{kg} / \mathrm{ha} / 6$ months) were found to be ranged from $2589.40 \pm 14.40$ to $3616.0 \pm 16.74$. The minimum value of production was recorded with the treatment $T_{1}$ whereas the maximum value was recorded with the treatment $\mathrm{T}_{3}$.

Table 5. Variation in the mean values of growth parameters under different treatments during the study period.

\begin{tabular}{llll}
\hline Treatments parameters & $\mathbf{T}_{\mathbf{1}}$ & $\mathbf{T}_{\mathbf{2}}$ & $\mathbf{T}_{\mathbf{3}}$ \\
\hline Initial Weight $(\mathrm{g})$ & $3.00 \pm 0.00^{\mathrm{a}}$ & $3.00 \pm 0.00^{\mathrm{a}}$ & $3.00 \pm 0.00^{\mathrm{a}}$ \\
\hline Final Weight $(\mathrm{g})$ & $32.17 \pm 0.43^{\mathrm{a}}$ & $34.98 \pm 0.30^{\mathrm{b}}$ & $40.44 \pm 0.32^{\mathrm{c}}$ \\
\hline Weight Gain $(\mathrm{g})$ & $29.16 \pm 0.43^{\mathrm{a}}$ & $31.17 \pm 0.30^{\mathrm{b}}$ & $37.44 \pm 0.32^{\mathrm{c}}$ \\
\hline ADG $(\mathrm{g})$ & $0.16 \pm 0.01^{\mathrm{a}}$ & $0.17 \pm 0.02^{\mathrm{b}}$ & $0.21 \pm 0.04^{\mathrm{c}}$ \\
\hline SGR $\left(\% \mathrm{bwd}^{-1}\right)$ & $1.30 \pm 0.03^{\mathrm{a}}$ & $1.35 \pm 0.05^{\mathrm{b}}$ & $1.43 \pm 0.01^{\mathrm{c}}$ \\
\hline FCR & $2.97 \pm 0.02^{\mathrm{a}}$ & $2.64 \pm 0.02^{\mathrm{b}}$ & $2.20 \pm 0.01^{\mathrm{c}}$ \\
\hline PER & $1.17 \pm 0.02^{\mathrm{a}}$ & $1.18 \pm 0.01^{\mathrm{a}}$ & $1.30 \pm 0.01^{\mathrm{b}}$ \\
\hline Condition factor $(\mathrm{k})$ & $1.04 \pm 00^{\mathrm{a}}$ & $1.03 \pm 03^{\mathrm{a}}$ & $1.09 \pm 05^{\mathrm{a}}$ \\
\hline Survival rate $(\%)$ & $72.43 \pm 1.20^{\mathrm{a}}$ & $75.82 \pm 1.15^{\mathrm{b}}$ & $80.45 \pm 0.87^{\mathrm{c}}$ \\
\hline Production $99(\mathrm{~kg} /$ ha/6months) & $2589.40 \pm 14.24^{\mathrm{a}}$ & $2948.10 \pm 20.70^{\mathrm{b}}$ & $3616 \pm 16.74^{\mathrm{c}}$ \\
\hline
\end{tabular}

**Figures in the same raw having same superscripts are not significantly different. 


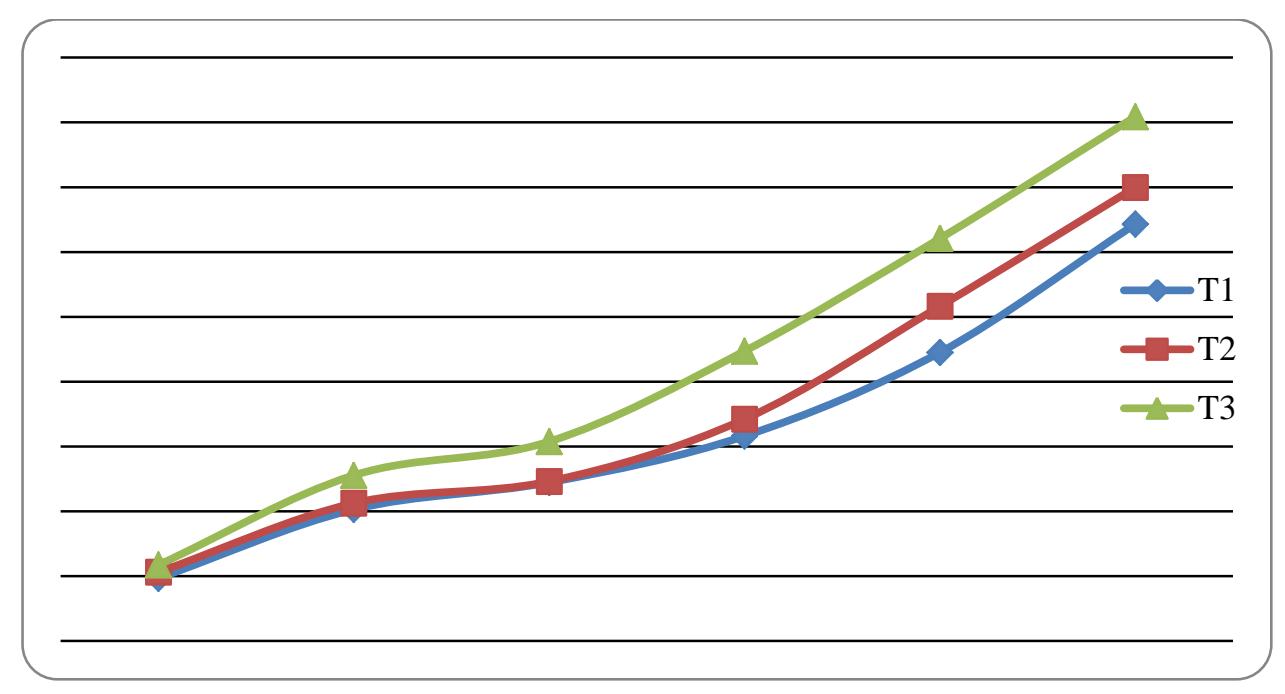

Figure 1. Variation in the monthly values of weight under different treatments during the study period.

\subsection{Economics}

Economies of different dietary protein level containing feeding on Mystus cavasius for compensatory growth under different treatments is summarized in Table 6. Variations in the mean values of total cost (BDT/ha/6months), total income (BDT/ha/6months) and net profit (BDT/ha/6months) among the treatments are shown in Figure 2. Variations in the mean values of CBR among the treatments are shown in Figure 3. A simple economic analysis was performed to estimate the Cost Benefit Ratio (CBR) from this culture operation. The total cost, total income, net benefit and cost benefit ratio were significantly different $(p<0.05)$ among the treatments. The highest total cost $(607110 \pm 1865.14 \mathrm{Tk} / \mathrm{ha} / 6$ months $)$ was found with the treatment $\mathrm{T}_{3}$ whereas lowest cost $\left(521380 \pm 772.39\right.$ was found with the treatment $T_{1}$. Total income varied from $1035700 \pm 5696.78$ to $1808000 \pm 8361 \mathrm{Tk} / \mathrm{ha} / 6$ months. Highest total income was found with the treatment $\mathrm{T}_{3}$ whereas lowest income was found with the treatment $T_{1}$. The best result for net benefit $(1200900 \pm 9807 \mathrm{Tk} / \mathrm{ha} / 6$ months) was found with treatment $\mathrm{T}_{3}$. Cost benefit ratio (CBR) were found $0.99 \pm 0.01,1.40 \pm 0.02$ and $1.98 \pm 0.02$ in treatment $\mathrm{T} 1, \mathrm{~T}_{2}$ and $\mathrm{T}_{3}$ respectively.

Table 6. Economies of different dietary protein level containing feeding on Mystus cavasius for compensatory growth under different treatments.

\begin{tabular}{llll}
\hline Testaments economics & $\mathbf{T}_{\mathbf{1}}$ & $\mathbf{T}_{\mathbf{2}}$ & $\mathbf{T}_{\mathbf{3}}$ \\
\hline Pond preparation (BDT/ha) & $1000 \pm 0.00^{\mathrm{a}}$ & $1000 \pm 0.00^{\mathrm{a}}$ & $1000 \pm 0.00^{\mathrm{a}}$ \\
\hline Cost of lime (BDT/ha) & $10631 \pm 0.00^{\mathrm{a}}$ & $10631 \pm 0.00^{\mathrm{a}}$ & $10631 \pm 0.00^{\mathrm{a}}$ \\
\hline Cost of fertilizer (BDT/ha/6months) & $4050 \pm 0.00^{\mathrm{a}}$ & $4050 \pm 0.00^{\mathrm{a}}$ & $4050 \pm 0.00^{\mathrm{a}}$ \\
\hline Cost of fry (BDT/ha/6months) & $75450 \pm 0.00^{\mathrm{a}}$ & $75450 \pm 0.00^{\mathrm{a}}$ & $75450 \pm 0.00^{\mathrm{a}}$ \\
\hline Feed cost (BDT/ha/6 months) & $324170.00 \pm 1412.69^{\mathrm{a}}$ & $356100 \pm 1394.41^{\mathrm{b}}$ & $410380 \pm 1481.36^{\mathrm{c}}$ \\
\hline Harvesting cost (BDT/ha) & $20000 \pm 0.00^{\mathrm{a}}$ & $20000 \pm 0.00^{\mathrm{a}}$ & $20000 \pm 0.00^{\mathrm{a}}$ \\
\hline Labour cost (BDT 300/day) & $35000 \pm 0.00^{\mathrm{a}}$ & $35000 \pm 0.00^{\mathrm{a}}$ & $35000 \pm 0.00^{\mathrm{a}}$ \\
\hline Total cost (BDT/ha/6 months) & $521380 \pm 772.39^{\mathrm{a}}$ & $553310 \pm 1728.34^{\mathrm{b}}$ & $607110 \pm 1865.14^{\mathrm{c}}$ \\
\hline Total return (BDT/ha/6months) & $1035700 \pm 5696.78^{\mathrm{a}}$ & $1326600 \pm 9316.30^{\mathrm{b}}$ & $1808000 \pm 8368.24^{\mathrm{c}}$ \\
\hline Benefit (BDT/ha/6months) & $514370 \pm 4967.04^{\mathrm{a}}$ & $773330 \pm 921.20^{\mathrm{b}}$ & $1200900 \pm 9807.42^{\mathrm{c}}$ \\
\hline CBR & $0.99 \pm 0.01^{\mathrm{a}}$ & $1.40 \pm 0.02^{\mathrm{b}}$ & $1.98 \pm 0.02^{\mathrm{c}}$ \\
\hline
\end{tabular}

**Figures in the same raw having same superscripts are not significantly different.

(Fry cost was 1.70 BDT/piece; Market price of Gulsha (Mystus cavasius) was of 400, 450 and 500 for treatment $\mathrm{T}_{1}, \mathrm{~T}_{2}$ and $\mathrm{T}_{3}$ respectively. Leasing cost was not included) 


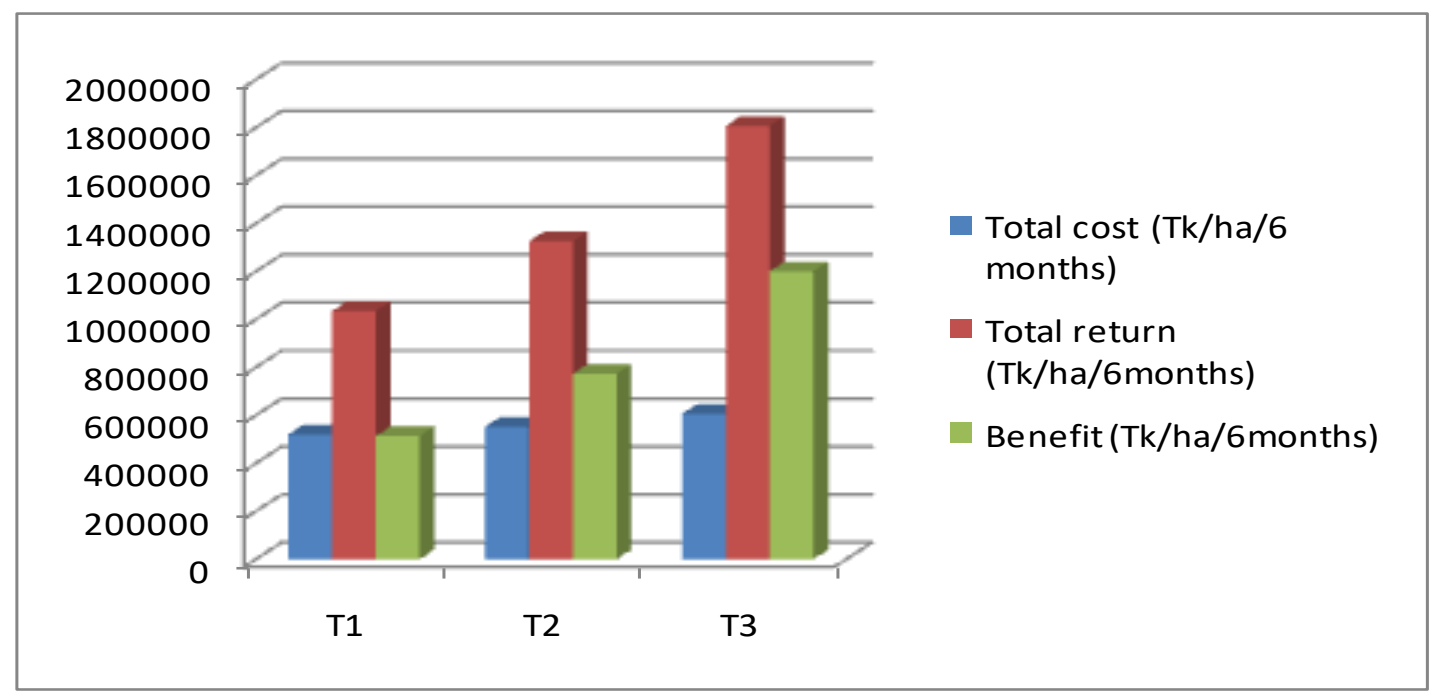

Figure 2. Variation in the mean values of total cost (BDT/ha/6months), total income (BDT/ha/6months) and net profit (BDT/ha/6months) among the treatments.

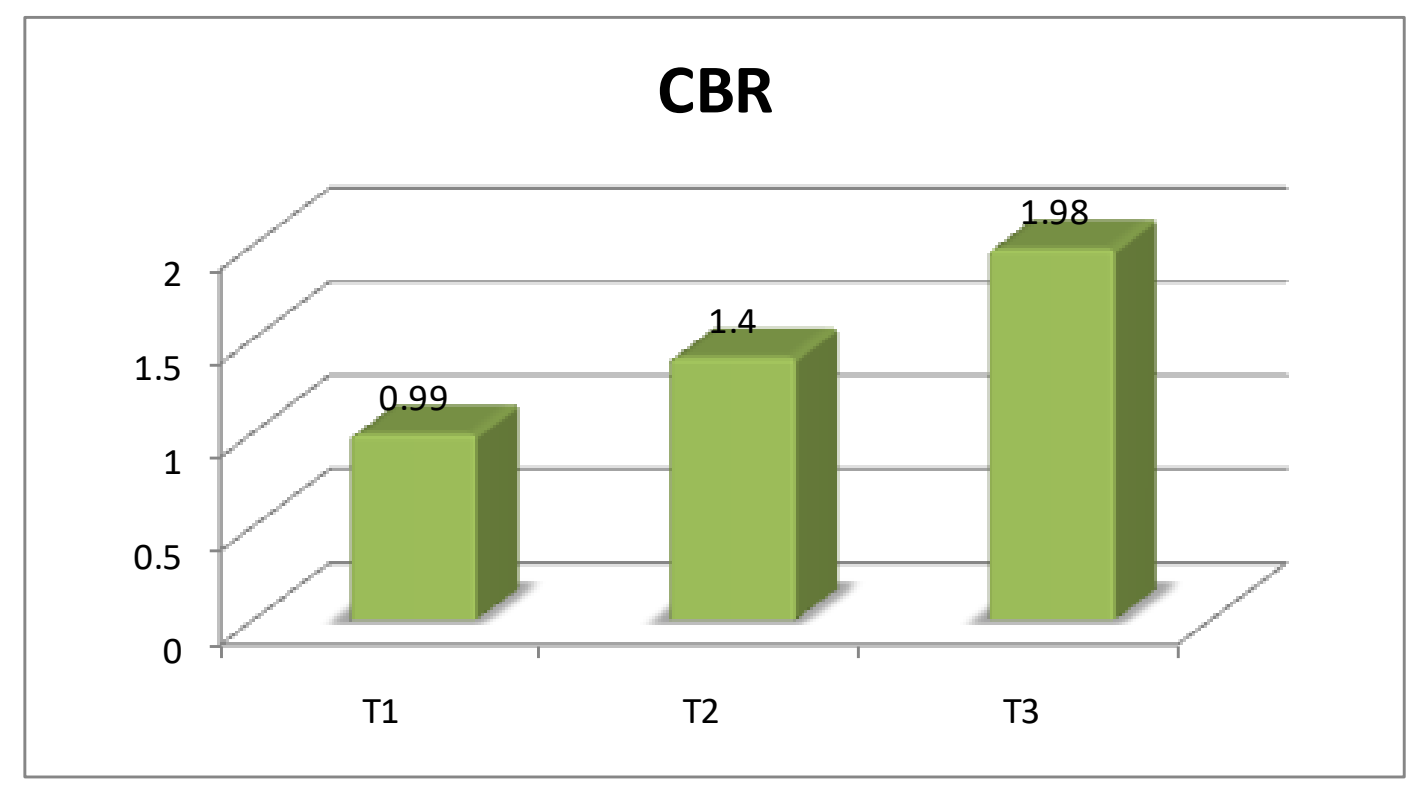

Figure 3. Variation in the mean values of CBR among the treatments.

\section{Discussion}

\subsection{Water quality parameters}

4.1.1. Water temperature $\left({ }^{\circ} \mathrm{C}\right)$

Temperature is a very important parameter for optimum growth in aquaculture because it affects feed utilization, growth and maturation of fish. The mean temperature of different treatments was investigated to be ranged from $25.01 \pm 0.34$ to $26.13 \pm 0.76$. Mondol et al. (2011) was also found more or less similar result of the mean value of water temperature and it was $26.0 \pm 5.80$. The highest growth was found at $25.01 \pm 0.34$. The result was found more or less likely to that of Kohinoor et al. (2004) in the culture pond of Mystus cavasius, Siddiqy et al. (2015) and Begum et al. (2008) in the culture pond of Mystus gulio and in case of whereas Sharma and Dutta (2012) found the water temperature around 30. Faruk et al. (2012) found water temperature varied from 25 to 33 in tilapia culture pond. Samad et al. (2005) found in cat fish pond water temperature varied from $29.00^{\circ} \mathrm{C}$ to $30.6^{\circ} \mathrm{C}$ that was similar to those obtained in the present study.

\subsubsection{Water transparency $(\mathrm{cm})$}

Water transparency is a gross measure of pond productivity. It acts as an index of productivity of a water body. According to Berger et al. (2006) it is closely related to the phytoplankton abundance. The transparency of 
water in the present study among three treatments were in between $27.64 \pm 0.23$ to $28.79 \pm 0.58$. According to Wahab et al. (1995) the transparency of productive water should be $40 \mathrm{~cm}$ or less. This finding was agreed with the present finding and it is indicating good condition of biological productivity of the study ponds. The present finding was also agreed with Begum et al. (2008) in Mystus gulio culture pond, but the result found from Siddiqy et al. (2015) with Kohinoor and Rahman ((2015) was significantly different to the present findings. The reason might be due to the difference in type and location of water body. Haque et al. (2005) reported the water transparency was of 17 to $32 \mathrm{~cm}$ and 20 to $35 \mathrm{~cm}$ respectively in catfish rearing ponds. This finding was also agreed to the present findings prominently. Mondal et al. (2010) found the suitable water transparency for the growth of Tilapia varied from 25 to $30 \mathrm{~cm}$.

\subsubsection{Dissolved Oxygen (mg/l)}

The single most important parameter in a culture pond is the dissolved oxygen (DO). A general statement of Ridha (2011) that the suitable dissolve oxygen of water body for fish culture would be 5 to $8 \mathrm{mg} / \mathrm{l}$. The result of this present study was revailing the acceptable value with this finding strongly. There was no significant difference of dissolve oxygen among the treatments and the level is above $5 \mathrm{mg} / \mathrm{l}$. Kohinoor et al. (2004) and Begum et al. (2008) found more or less likely similar value to the present study whereas Siddiqky et al. (2015) with Sharma and dutta (2012) found significantly different value to the present study. According to Rahman (1992) DO content of a productive pond should be $5 \mathrm{mg} / \mathrm{l}$ or more. Samad et al. (2005) recorded the DO level was of $4.70 \pm 0.61$ to $5.40 \pm 0.34$ for the better growth of Clarias batrachus. This result was also strongly agreed with Ferdous et al. (2014) in which the DO content varied from 5 to $6.5 \mathrm{mg} / \mathrm{l}$ in Tilapia fry rearing pond.

\subsection{4. $\mathrm{p}^{\mathrm{H}}$}

$\mathrm{P}^{\mathrm{H}}$ is treated as another important productivity index of a culture pond. Most of the water bodies having good or moderate aquaculture condition found $\mathrm{P}^{\mathrm{H}}$ within the range of 6.5 to 8.5. Slightly alkaline $\mathrm{P}^{\mathrm{H}}$ is most suitable for fish culture. The $\mathrm{P}^{\mathrm{H}}$ level of the present study varied from $7.02 \pm 0.11$ to $7.73 \pm 0.02$ in the pond water under different dietary protein level treatments. These findings were above the minimal values or within the acceptable range, as reported by Begum et al. (2008) in Mystus gulio rearing pond, Sharma and Dutta (2012) in Ompok Pabo rearing pond, and with Kohinoor and Rahman (2015) in the experiment of Mystus cavasius cage culture in river water. Boyd (1990) reported the acceptable range was of 6.5 to 9.0. The present result was strongly agreed within this range. Samad et al. (2005) also recorded alkaline $\mathrm{P}^{\mathrm{H}}$ (8.1 to 8.8) in the experiment of $C$. batrachus in ponds. The present findings were also revealing the findings of Saha et al. (2003) and Samad et al. (2017).

\subsubsection{Alkalinity (mg/l)}

Alkalinity does not play a direct role in aquatic biotic production. It creates a favorable condition for higher abundance of essential nutrients and this is the most important reason for higher biological productivity in alkaline waters than in acidic waters. But Rahman (1992) reported that highly alkaline condition was not favorable for biological production. The total alkalinity values found in the present study were within the suitable range $(137.67 \pm 1.53$ to $140.00 \pm 1.00)$. Samad et al. (2014) found the alkalinity, 86 to 167 in the experiment of $C$ batrachus and this finding supports the present findings strongly. Haque et al. (2005) observed the average total alkalinity result above $100 \mathrm{mg} / \mathrm{l}$ in their experiments. Samad et al. (2016) also found the total alkalinity range more or less 96 to 120 in the experiment of Labeo bata. All these experimental findings were strongly agreed with the findings of the present study. The higher value of Alkalinity during the study period might be due to low rainfall and evaporation of water. Boyd (1998) found that the natural fertility of pond water increases with the increase in total alkalinity up to at least $150 \mathrm{mg} / \mathrm{l}$.

\subsubsection{Ammonia-Nitrogen (mg/l)}

Ammonia nitrogen has a toxic effect on fish, the lower the value better for culture. But the presence of ammonia in culture pond is a very common phenomena due to natural fish metabolism and microbiological decay of organic matter. The finding of present study (ranged $.016 \pm .002$ to $.020 \pm 0.003$ ) is supported with the observation of Nahar et al. (2000). According to Boyd (1998) the observed low concentration of total ammonia utilization by phytoplankton and according to Boyd (2000) the cause might be due to the oxidation of ammonia to nitrate, especially in high dissolve oxygen conditions. Mensah et al. (2014) found ammonia nitrogen from 0.02 to 0.05 $\mathrm{mg} / \mathrm{l}$ in Tilapia culture pond. This finding was more or less similar to the finding of this present study. Alim (2005) recorded the ammonia nitrogen content varied from $0 \mathrm{mg} / \mathrm{l}$ to $1.00 \mathrm{mg} / \mathrm{l}$. Milstein et al. (2009) recorded 0.6 to $0.29 \mathrm{mg} / \mathrm{l}$, Alim (2005) recorded the maximum ammonia nitrogen content was of $1.00 \mathrm{mg} / \mathrm{l}$ and Kadir et al. (2007) found 0.11 to $0.52 \mathrm{mg} / \mathrm{l}$. These findings were higher than the findings of present study. The reason 
might be due to lack of knowledge in feeding regime. The concentration of ammonia of this present study were within suitable range.

\subsection{Fish growth parameters}

Understanding the dietary protein requirement of Gulsha (Mystus cavasius) becomes a pre-requisite for the development of balanced nutrition, cost effective and efficient feed for culturing practice. In the present study different types of dietary protein containing feed had a significant effect on production.

In the present study, growth and conversion efficiencies increased with increasing dietary protein levels from 29 to $35 \%$. Although growth of the fish levelled when reared on 35\% protein in the diet. The increase in growth was statistically significant and feeding fish with $35 \%$ protein level was economical. However an excellent conversion efficiency was found with $35 \%$ protein level. All the growth parameters estimated here are discussed below

\subsubsection{Final weight $(\mathrm{g})$}

The highest final weight (40.44 \pm 0.32$)$ of Mystus cavasius was obtained with the treatment $\mathrm{T}_{3}$ receiving $35 \%$ protein level. The harvesting weight showed significant difference in treatment $T_{3}$ followed by $T_{2}$ and $T_{3}$. Kohinoor et al. (2004) had found the same trend of final weight of Mystus cavasius (41.42 \pm 6.20$)$ which was fairly similar to the finding of this present study. Siddiqui and Khan (2008) noted significantly different final weight $(23.65 \pm 0.02)$ of $H$. fossilis at $35 \%$ protein level for 8 weeks experimental period. A different trend was found in this finding with the present study, the cause might be due to species variation and difference in experimental period.

\subsubsection{Weight gain $(\mathrm{g})$}

The highest weight gain $(37.44 \pm 0.32)$ was found at $\mathrm{T}_{3}$. There was significant difference of weight gain among the treatments. The higher increasing trend of weight gain in this study was obtained in second and last month of culture period and there was decline in growth in third month. This decline might be due to temperature fall in water. The highest weight gain of this study was supportive to that of recorded by Kohinoor et al. (2004). Paul et al. (2012) found the optimum protein level for Ompok pabda was about 33\% for maximum weight gain. The results were in agreement with Horabargus brachysoma fingerlings where crude protein level was $35 \%$ (Giri et al. 2011) as like the present study, but it was higher than C. batrachus where $30 \%$ crude protein was in the diet (Chuapoehuk, 1987). From the study of Ompok pabda the findings of Mollah and Sarowar (2009) also agreed with the findings of the present study. Comparatively lower protein level in the diets of treatment $\mathrm{T}_{1}$ and $\mathrm{T}_{2}$ had lower growth performance of fish, it might be due to higher levels of carbohydrates in their diets which supports to the observations of Jantrarotai et al. (1994) in hybrid catfish. Amin et al. (2010) reported in case of Rita rita the highest weight gain result $(400.69 \pm 1.05)$ at $45.75 \%$ protein level for 1 -year culture period. The finding was different to the present study because of the present study period was about 6 month and dietary protein level was $35 \%$.

\subsubsection{Average daily gain (ADG)}

During the investigation of the present study the highest ADG $(0.21 \pm 0.04)$ was found in $\mathrm{T}_{3}$ and there was significant difference found among the treatments. Panase and Mengumphan (2015) also found the same trend as like in the present experiment. Rahman et al. (2013) found the highest result $(0.134 \pm 0.024)$ at $35 \%$ protein level in case of Heteropneustes fossilis for 60 days experiment and the result was lower than that of present study. Amin et al. (2010) recorded the highest ADG (1.10) at 45\% protein level in case of Rita rita for 1 year culture. This finding was better than present findings because both the culture period and protein level was prominently higher than present experiment. Samad et al. (2005) found the best ADG, $(0.138 \mathrm{~g})$ in the experiment of $C$ batrachus. Sangrattanakhul (1989) found the ADG of A. testudineus fish ranging from 0.100 to $0.120 \mathrm{~g}$ and this finding was lower than the findings of present study. Both of the findings were supportive to the present findings. Samad et al. (2004) found a different result of ADG (10.18 mg) in case of Heteropneustes fossilis fry in ponds. The variation might be due to difference in culture system and species variation.

\subsubsection{SGR (\% bwd $\left.{ }^{-1}\right)$}

Among all the investigations of specific growth rate (\% per day) of Gulsha (Mystus cavasius) in all the treatments the highest SGR $(1.43 \pm 0.01)$ was found in $\mathrm{T}_{3}$ containing dietary protein level $35 \%$. As water temperature has direct effect on the growth and metabolism of fish, fish during the culture period of second and last two months showed major increment in growth until harvesting. More or less like this Kohinoor et al. 
(2004) found the best SGR for Mystus cavasius was of $1.23 \%$ and Paul et al. (2012) recorded the SGR value was of $1.34 \%$ at $33 \%$ crude protein level and $1.20 \%$ at $38 \%$ crude protein level in case of Ompok pabda.These findings resembles to Rahman et al. (2013) and the highest SGR findng (1.45 \pm 0.04$)$ was at 35\% protein level in case of Heteropneustes fossilis which was similar to the highest finding of the present study. Unlike this, a completely different result (109.62\%) was obtained by Amin et al. (2010) which was totally different to the present findings. The reason might be due to the variation of environmental or geographical conditions, higher protein level and species variation comparison with the present study. Samad et al. (2004) found the best SGR was of 2.53 in the fry rearing experiment which was better to the findings of present study. The variation occurred because of the experiment was conducted on fry culture when the present study was for grow out culture. The highest SGR obtained in the experiment of Hossain et al. (1998) was of $1.80 \%$ for $H$ fossilis by supplying diet which was comparatively higher than the present findings, the reason might be due to species variation.

\subsubsection{Food Conversion Ratio (FCR)}

FCR is the measure of diet efficiency. The lowest the value the best for the culture, and the less amount of feed is needed to produce 1 unit weight of fish. In this study the best FCR value was found $2.20 \pm 0.01$ in treatment $T_{3}$ containing 35\% protein level. This finding was concur with those of Siddiky et al. (2015) in which the FCR value ranged from 1.50 to 2.00 for Mystus gulio and Paul et al.(2012) for Ompok pabda the FCR was of 2.17 at $33 \%$ protein level. Samad et al. (2004) recorded the best FCR value for fry rearing of $H$ fossilis was 3.25. This finding was different to the findings of present study, it occurred because the experiment was on the fry culture while the present study was for grow out culture of Mystus cavasius. The FCR value of the present experiment were also in agreement with the report of Webster et al. (1992) in cage reared channel catfish. But Amin et al. (2010) found the FCR value was of 0.15 in case of Rita rita at $43.50 \%$ protein level and which was significantly different to the findings of present study. The FCR value obtained in this study was decreased with the increase of Protein level at the range of 29 to $35 \%$.

\subsubsection{Protein Efficiency Ratio (PER)}

PER is the indicator of protein quantity and quality in the fish diet. In the present study PER is increased with the increase of dietary protein level. This parameter is used to estimate protein utilization and its conversion into fish weight gain. In this study PER was recorded 1.17 $\pm 0.02,1.18 \pm 0.01,1.30 \pm 0.01$ in the treatment $\mathrm{T}_{1}, \mathrm{~T}_{2}$ and $\mathrm{T}_{3}$ respectively. The highest value was observed in $\mathrm{T}_{3}(1.30 \pm 0.01)$ where the protein level was $35 \%$. The result of present study showed that possibly dietary protein was efficiently utilized by fish for protein synthesis which was an accordance with Kikuchi et al. (1992) and Lee et al. (2000) reported that PER values of olive flounder increased with increasing dietary protein level. Beside this finding from the experiment of Ompok pabda Paul et al. (2012) reported the same trend (1.4 at 33\% protein level) in his study. Siddiqui and Khan (2008) reported the value of PER was of $1.51 \pm 0.09$ in case of Heteropneustes fossilis at 35\% dietary protein level and different patterns of changes in PER in relation to dietary protein level and found the relationship among the dietary protein level which was increased with the increasing of it. This finding is similar to the trend of the findings of this study. But different result was found in the experiment of Berger and Halver (1987). Beside this finding in contrast to present study Bai et al. (1999); Kim et al. (2004); Hossain et al. (2010); Zhang et al. (2010) recorded different results to the present study. However Dabrowski (1979) reported that the relationship between dietary protein and PER differs from species to species.

\subsubsection{Condition Factor $(\mathrm{K})$}

Fish biometrics in terms of Condition Factor $(\mathrm{K})$ or the well- being of fish indicate the body condition of fish. If the Condition factor $\mathrm{K}$ value is 1 , it is considered as standard value. In this study condition factor was increased with protein level increment in the diets by fish. There was no significant difference among the treatments but the best value $(1.09 \pm 0.05)$ was found within the treatment $T_{3}$. All the findings of the present study revealed the value above 1 which suggests that the fish were in good condition; however, condition factor based on the LWR is an indicator of the changes in food reserves and therefore an indicator of the general fish condition (Hossain et al. 2012). In general, the seasonal cycle in fish's condition suggested a relationship to gonadal development. According to Hossain et al. (2006b), the condition factor of Mystus vittatus (Bloch 1794) (Siluriformes: Bagridae) was constant during the pre-spawning period, decreased in the period of spawning and was lowest immediately after spawning. However only the seasonal data were used during his study thus it is difficult to compare among the condition of fishes throughout the year. Rahman et al. (2013) found the best $\mathrm{K}$ value $(1.06 \pm 0.04)$ at $35 \%$ protein level in the experiment of Heteropneustes fossilis this finding is supportive to the 
findings of the present experiment. Findings of Panase and Mengumphan (2015) was also reported the same trend in their hybrid catfish rearing experiment. Kim and Lall (2001) found different result to the present findings. The reason might be due to variation in geographical condition, water quality parameters and species variation.

\subsubsection{Survival rate $(\%)$}

The best survival rate $(80.455 \pm 0.87)$ was recorded at treatment $\mathrm{T}_{3}$. The recorded result of Siddiky et al. (2015) for Mystus gulio found much higher (94.34\%) than this study at 33\% protein level whereas Begum et al. (2008) reared Mystus gulio seed at stocking density 450/decimal and obtained the survival rate more or less $70 \%$. This finding is prominently lower than findings discussed above. Rahman et al. (2013) found $93.33 \%$ survival rate at $35 \%$ protein level in case of Heteropneustes fossilis. The result was also significantly different to the present finding. The difference might be caused due to species variation, environmental factors \& stocking size. The most diversified finding was recorded by Kohinoor and Rahman (2015) in case of Mystus cavasius and the rate was of $66 \pm 3.14$ (highest) in which the stocking density was of $500 / \mathrm{m} 3$. In case of Rita rita, Amin et al. (2010) found $88.8 \%$ survival rate at $43.50 \%$ protein level. Samad et al. (2004) found survival rate varied from $75-86 \%$ In case Heteropouneustes fossilis. This finding was more or less similar to the findings of the present study. In the experiment of Ompok pabda, formulated feed with the addition of piscimix helps to combat mortality, enhances survival rate and allows larger growth (Mukherjee et al. 2002). In Clarias batrachus, the artificial feed was prepared with a mixture of mollluscan meat (70\%), egg, (20\%) soybean cake (10\%) and vitamin B premix $(500 \mathrm{mg} / \mathrm{kg}$ feed) and then applied in the form of dough balls (Mahapatra, 2004). However all these researchers concluded with gradual increase of protein level to increase the survival rate. In contrast, Samad et al. (2014) found the best survival rate $(94.5 \pm 1.56)$ of $C$ batrachus which was significantly different to the present findings. The reason might be due to the species variation and variation in culture system.

\subsection{Production (kg/ha)}

Higher production and economic solvency is the main target of aquaculture. The best production was recorded $3616.0 \pm 16.74$ at treatment $\mathrm{T}_{3}$. Kohinoor et al. (2004) in case of Mystus cavasius observed the highest production $1535 \pm 71 \mathrm{~kg} / \mathrm{ha}$ at $25 \%$ protein level and the total number of fry was 50000 whereas the total number of fry was 45000 in the present study. This finding is in a slight contrast to the present finding as the protein level was higher in the present experiment. Some natural phenomena might be play a significant role for this finding. Similar result with the present experiment was observed with the Production of Mystus gulio (2067 $\mathrm{Kg} / \mathrm{ha}$ ) by Siddiky et al. (2015) at 30\% protein level. Rahman et al. (1997) conducted an experiment on effects of different feeds on the growth of Clarias batrachus and obtained the best result by using $40 \%$ protein containing feed. Culture of small indigenous fish such as Gulsha (Mystus cavasius), pabda, sharpunti, koi, mola, chela, has not yet been attempt on large scale in this country (Kohinoor 2004). Consequently, published information's on production of small indigenous fish species in freshwater ponds are rather little. Akhteruzzaman (1988) reported that the production of koi (Anabas testudineus) was $450 \mathrm{~kg} / \mathrm{ha} / 5$ months where the supplementary feeds were rice bran, mustard oil cake, and fish meal. In another study Akhteruzzaman et al. (1991) reported that in monoculture condition the production of (P sarana) was $1200 \mathrm{~kg} / \mathrm{ha} / 6$ months. Samad $e t$ al. (2004) obtained the production of $1710 \mathrm{~kg} / \mathrm{ha}$ in the culture of (Heteropneustes fossilis) during the culture period of 3 months. However, present study reveals that feeds containing 35\% protein level is the best rather than other feeds. This study is also giving good results which can support fish farmers and can improve the economics.

\subsection{Economics (BDT/ha)}

The cost benefit analysis of Gulsha (Mystus cavasius) monoculture was done to estimate the CBR that has been generated from this type of culture. Significant difference was found among the treatments for the total cost. The cost of production was higher in treatment $T_{3}$. This might be due to increment of feed cost with the treatment $\mathrm{T}_{3}$ (feeding with $35 \%$ protein level).

Highest income was found with treatment $T_{3}$ whereas lowest income was found with the treatment $T_{1}$. Significant difference was found among the treatments for the total income.

The highest net profit $(1200900 \pm 9807)$ was obtained from treatment $T_{3}$ where the dietary protein level was of $35 \%$. And the lowest net profit was found with treatment $T_{1}$. which is completely different to the net benefit of the experiment of Kohinoor et al. (2004) and it might be due to low dietary protein containing feed and changed marketing condition with the passage of time. Hussain et al. (1989) analyzed the cost and benefit of Nile tilapia (Oreochromis niloticus) in monoculture condition and got the net benefit of TK 72,827/ha/6 months. 
Where fish were feed with rice bran and mustard oil cake. The net benefit of rajpunti (Puntius gonionotus) Kohinoor et al. (1993) reported that TK 68,135 to 75,028/ha/6 months could be achieved by applying supplementary feed and fertilization. Whereas Kohinoor (2000) got the profit of Tk 32910/ha/6 months monoculture of small indigenous fish punti (Puntius sophore).

However, these findings were not very encouraging for the production and economic return of Gulsha (Mystus cavasius) in monoculture management comparision with the present study. It might be due to the variation of culture system and the marketing condition with the passage of time. By the recent period of time culture of Gulsha (Mystus cavasius) is seems to be profitable in few researches. In the present study the CBR of treatment $\mathrm{T}_{3}$ was more profitable and it was $1.98 \pm 0.02$. Samad et al. (2016) found more or less similar best C.B.R (1:1.78) in the experiment of nursery culture of Labeo bata and this finding was more or less similar to the present study. But the best finding of Samad et al. (2014) in case of Clarias batrachus was of 1:1.24 which was significantly different to the present findings. The cause might be due to species variation, variation of study period and stocking size.

\section{Conclusions}

In the present study, considering water quality, growth rate, production and economics, treatment $\mathrm{T}_{3}$ (used feed which contains $35 \%$ protein) was found the best among the treatments. Thus, the present study indicated that feed has direct effects on the growth and production of Mystus cavasius culture under pond condition. A feed that contain more protein is best suited that the farmer can maximize their benefit by culturing Mystus cavasius providing high protein feeds instead of commonly used low protein feeds for commercial culture.

\section{Acknowledgements}

The authors express their gratitude to the Chairman, Department of Fisheries, University of Rajshahi for his kind permission to use the aquatic lab and having all the facilities from the Department to conduct the research work. The $M$ cavasius seed supplied by Md. Sadiqul Islam owner of the "Sayeed Fisheries" is duly acknowledged.

\section{Conflict of interest}

None to declare.

\section{References}

Akhteruzzaman M, 1988. A study on the production of koi fish (Anabus testudineus) under semi intensive culture system. J. Zool., 3: 39-43.

Akhteruzzaman M, AHM Kohinoor, MS Shah and MG Hussain, 1991. Observation on the induced breeding of Mystus cavasius. Bangladesh J. Fish., 14:78-82.

Alim MA, MA Wahab and A Milstein, 2005. Effects of increasing the stocking density of large carps by $20 \%$ on 'eash' carp-small fish polyculture of Bangladesh. J. Aqua. Res., 36: 317-325.

Amin MR, FA Mollah, MR Ali and M Nahiduzzaman, 2010. Effects of different feed items on the growth and survival of endangered riverine catfish Rita rita (Hamilton). Univ. J. Zool. Rajshahi. Univ., 28:11-14.

Begum M, AA Mamun, HK Pal, MA Islam and MJ Alam, 2008. Effects of stocking density on growth and survival of Mystus gulio in nursery ponds. Bangladesh J. Fish. Res. 12: 179-186.

Berger A and JE Halver,1987. Effect of dietary protein, lipid and carbohydrate content on the growth, feed efficiency and careass composition of striped bass, Morone saxatilis (Walbaum) fingerlings. Aqua. Fish. Manage., 18:345356.

Bai SC, XJ Wang and ES Cho 1999. Optimum dietary protein level for maximum growth of juvenile yellow puffer. Fish. Sci., 65:380-383.

Berger CBN, M Gugger, M Bouvvy, F Rusconi, A Coute, M Troussellier and C. Bernard, 2006. Seasonal dynamics and toxicity of cylindrosperopsis raciborskii'm lake guiers (Senegal, west africa). Fed. Eur. Microbiol. Soc., 57: 355-366.

Boyd CE, 1998. Water quality for pond aquaculture. Research and development series No. 43. Alabama Agricultural Experiment station. Auburn University, Alabama, USA. 37.

Boyd CE, 2000. Water quality-an introduction. Kluwer Academic Published Boston, Massachusetts. 36-68.

Boyd CE, 1990. Water quality in ponds for aquaculture. J Alabama Agriculture Experiment Station, Auburn University, Alabama, 462.

Chuapoehuk W, 1987. Protein requirement of walking catfish, Clarius batrachus (Linnaeus) fry. Aquaculture, 63: 215-219. 
Craig S and LA Helfrich, 2002. Understanding fish Nutrition, Feeds and Feeding. Department of Fisheries and Wild Life Sciences, Virginia Tech, 420-456.

Dabrowski K, 1979. Feeding requirement of fish with Particular attention to common carp: a review. Polish. Arch. Hydrobiol. 26:135-158.

Ferdous F, MA Masum and MM Ali, 2014. Influence of stocking density on growth performance and survival of monosex tilapia (Oreochromis niloticus) fry. Int. J. Fish. Aqua., 4: 99-103.

Giri SS, SK Sahoo, BN Paul, SN Mohanty and AK Sahu, 2011. Effect of dietary protein levels on growth, feed utilization and carcass composition of endangered bagrid catfish Horabagrus brachysoma (Gunther 1864) fingerlings. Aquacul. Nutri., 17:332-337.

Gupta S, 2014. A review on Mystus cavasius. a popular food fish of Indian Subcontinent. Int. J. Fau. Biol. Stud., 1: 27-31.

Hamilton F, 1822. An account of the fishes found in the river Ganges and it's branches. Constable and co, Edinburgh, $U K$.

Haque MM, MRU Sarkar and S Khan, 2005. Spawning periodicity of two Indian major carps, Labeo rohit (Ham.) and Cirrhina mrigala (Ham.). Bangladesh. J. Zool., 21: 9-26.

Hossain MY, MM Rahman, B Fulanda, MAS Jewel, F Ahmed and J Othomi, 2012. Length-weight and lengthlength relationships of five threatened fish species from the Jamuna (Brahmaputra River tributary) river, northern Bangladesh. J. App. Ichthyol., 28:275-277.

Hossain MA, K Afsana and AKMA Shah, 1999. Nutritional value of some small indigenous fish species (SIS) of Bangladesh. Bangladesh J. Fish. Res. 3:77-85.

Hossain MA, AHM Kohinoor and MG Hussain, 1998. polyculture of gulsha (Mystus cavastus Ham.) with rajpunti (Puntius gonionotus Bleeker) and silver carp (Hypophthylmichthys molitrix val.) in earthen ponds. Bangladesh J. Fish. Res., 2: 9-14.

Hossain MY, ZF Ahmed, PM Leunda, S Jasmine, J Oscoz, R Miranda and J Ohtomi, 2006. Condition. lengthweight and length-length relationships of the Asian striped catfish Mystus Vittatus (Bloch, 1794) (Siluriformes: Bagridae) in the Mathabhanga River. Southwestem Bangladesh. J. App. Ichthyol. 22:304-307.

Hossain MA, SM Almatar and CM James, 2010. Optimum dietary protein level for Juvenile silver pomfert, Pampus argenteus (Euphrasen). J. world. Aqua. Soc., 41:710-720

Hussain MG, MA Rahman, M Akhteruzzaman and AHM Kohinoor, 1989, Study on the production of Oreochromis niloticus under semi-intensive system in Bangladesh. Bangladesh J. Fish., 12:59-65.

Hutchinson GE, 1957. A treatise on limnology. Vol. 1. Geography Physics and Chemistry. John Wiley and Sons. Inc., New York, pp. 1115.

Islam MA, AH Chowdhury and M Zaman, 2001. Limnology of fish ponds in Rajshahi, Bangladesh. Ecol. Env., 7: 17.

IUCN Bangladesh. 2015. Red List of Bangladesh volume 5: Freshwater Fish. IUCN. International Union for conservation of Nature, Bangladesh country office, Dhaka. Bangladesh. xvi+360.

Jantrarotai W, P Sitasit and S Rajchapadee, 1994. The optimum carbohydrate to lipid ratio in hybrid Clarias catfish (Clarias macrocephalus $\times$ Clarias gariepinus) diets containing raw broken rice. Aquaculture, 127: 61-68.

Kadir A, MA Wahab, A Miistein, MA Hossain and MTI Seraji, 2007. Effects of silver carp and the small indigenous fish mola, Amblypharyngodon mola and punti, Puntius sophore on fish polycuture production. Aquaculture, 273:520-531.

Kikuchi K, H Sugita and T Watanabe, 1992. Effect of dietary protein level on growth and body composition of Japanese flounder, Paralichthys olivaceus. Suisanzoshoku, 40: 335-340.

Kim JD and SP Lall, 2001. Effects of dietary protein level on growth and utilization of protein and energy by juvenile haddock (Melanogrammus aeglefinus). Aquaculture, 195: 311-319.

Kim KW, XJ Wang, K Han, JC Kang, SC Bai, 2004. Optimum dietary protein level and protein-to-energy ratio for growth of juvenile Korean rockfish Sebastes schlegeli. J. World Aqua. Soc., 35: 305-314.

Kohinoor AHM and M Rahman, 2015. Growth and production performances of threatened small indigenous fish Galsha (Mystus caasiu) in cage system in the rive Brahmaputra, Mymensingh. Int. J. Fish. Aqua. Stud., 2:180-183.

Kohinoor AHM, 2000. Development of culture technology of three small indigenous fish-mola (Amblypharyngodon mola), punti (Puntius sophore) and chela (Chela cachius) with notes on some aspects of their biology. Ph.D. Thesis. Department of Fisheries Management, Bangladesh Agricultural University, Mymensingh. 
Kohinoor AHM, Akhteruzzaman and MS Saha, 1993. Production of Puntius gonionotus (Bleeker) in ponds. Bangladesh J. Zool., 21: 77-82.

Kohinoor AHM, M Begum and MG Hussain, 2004. Culture potentials of gulsha (Mystus cavasius) in monoculture management under different stocking densities. Bangladesh J. Fish. Res., 8: 95-100.

Lee SM, SH Cho, KD Kim, 2000. Effects of dietary protein and energy levels on growth and body composition of juvenile flounder, Paralichthys olivaceus. J. World Aqua. Soc., 36: 165-178

Mahapatra BK, 2004 Conservation of the Asiatic catfish. Clarias batrachus through artificial propagation and larval rearing technique in India. Aquacul. Asia, 9:8-9.

Mensah T, FKY Attipoe and K Atsakpo, 2014. Comparative growth study of Oreochromis niloticus and Sarotherodon galilaeus under two different culture regimes (hapa in pond and cage system). Int. J. Fish. Aqua. Stud., 1: 53-59.

Milstein A, MA Wahab, A Kadir, MFH Sagor and MA Islam, 2009. Effects of intervention in the water column and/or pond bottom through species composition on polycultures of large carps and small indigenous species. Aquaculture, 286: 246-253.

Mollah MFA and MN Sarowar, 2009. Growth performance and survival of larvae of Ompok pabda Produced from vitamin E treated female broodfish. Progress. Agric., 20:125-132.

Mondal MN, J Shahin, MA Wahab, M Asaduzzaman and Y Yang, 2010. Comparison between cage and pond production of thai climbing perch (Anabas testudineus) and tilapia (Oreochromis niloticus) under three management systems. J. Bangladesh Agril. Univ., 8: 313-322.

Mondol MRK, MMR Chowdhury and MM Rahman, 2011. Water quality of Garwha beel of Nawabganj district. Bangladesh. Bangladesh J. Prog. Sci. Tech., 9: 173-176.

Monentcham SE, V Pouomigne, P Kestemont, 2009. Influence of dietary protein levels on growth performance and body composition of African bonytongue fingerlings Heteriostis niloticus (Cuvier, 1829). Aquacul. Nutr., 16:144-152.

Nahar Z, AKMA Shah, RK Bhandari, MH Ali and S. Dewan, 2000. Effect of different feeds on growth, survival and production of african catfish (Clarias gariepinus Burchell). Bangladesh J. Fish. Res., 2: 121-126.

NRC (National Research Council), 2011. Nutrient requirements of fish and shrimp. Washington. DC: National Academy Press. pp. 392.

NRC, 1993. Nutrient Requirements of Warmwater Fishes and Shellfishes, National Academy Press, Washington. DC. pp. 102.

Panase P and K Mengumphan, 2015. Growth performance, length-weight relationship and condition factor of backcross and reciprocal hybrid catfish reared in net cages. Int. J. Zool. Res., 11: 57-64.

Paul BNL, S Das and SS Giri, 2012. Effect of dietary protein levels on growth of ompok pabda (Siluridae) Fry. Anim. Nutri. Feed Tech., 12: 241-246.

Rahman MS, 1992. Water quality management in aquaculture. BRAC prakashana. 66. Mohakhali. Dhaka-1212. Bangladesh. pp.75.

Rahman MA, A Badhra, N Begum and MG Hossain, 1997. Effects of some selective supplemental feeds on the survival and growth of catfish (Clarius batrachus Lin.) fry. Bangladesh J. Fish. Res., 1: 55-58.

Rahman MA, M Zaher, KM Azimuddin, S Yeasmine, MM Khan, A Arshad, 2013. Stocking density effects on growth and production of the threatened silurid catfish, Mystus cavasius (Hamilton) fingerlings in nursery ponds. Aquacul. Res., 44: 1132-1139.

Ridha MT, 2011. Evaluation of monosex culture of GIFT and non-improved strains of nile tilapia Oreochromis niloticus in recirculating tanks. Int. J. Aqua. Res., 3: 189-195.

Saha DC, S Devnath, NS Roy and S Dewan, 2003. Studies on the comparative efficiency of different fertilizer on the production of silver carp (Hypophthalmichthys molitrix) fry in nursery ponds. Bangladesh J. Fish., 11: 83-88.

Samad MA, AM Imteazzaman, IM Hossain and MS Reza, 2014. Effects of three different low cost feeds on growth performance of walking catfish (Clarias batrachus L.) in earthen ponds. Rajshahi Univ. J. Life Earth Agri. Sci., 42:1-10.

Samad MA, MA Islam and MA Khaleque, 2005. Effect of stocking density on the growth and survival rate of Magur (Clarias batrachus) fry in laboratory and nursery ponds. Pakistan J. Biol. Sci., 8:338-344

Samad MA, MA Islam, MA Khaleque, MR Amin and MS Alam, 2004. Fry rearing and culture of indigenous catfish, Shingi (Heteropneustes fossilis Bloch, 1794). Progress. Argi., 15: 121-131.

Samad MA, M Asaduzzaman, SM Galib, MM Kamal and MR Haque, 2010. Availability and consumer preference of small indigenous species (SIS) of the river Padma at Rajshahi, Bangladesh. Int. J. BioRes., 1: 27-31. 
Samad MA, MA Rasid, MR Haque, AK Paul and H Ferdaushy, 2016. Density-dependent growth of endangered Labeo bata (Hamilton, 1822) in nursery ponds. J. Env. Sci. Nat. Res., 9: 67-73.

Samad MA, M Farjana, SK Chatterjee, MM Rahman and SC Barman, 2017. Culture technique of endangered Notopterus chitala (Hamilton, 1822) with Oreochromis niloticus for domestication in pond habitat. Bangladesh J. Sci. Ind. Res. 52: 187-194.

Sangrattanakhul C, 1989. Effect of pelletized diets containing various levels of protein on growth and survival of Climbing perch. Anabas testudineus (Bloch). Master degree Thesis. Kasetsart University Bangkok, Thailand. pp.74.

Sarma D, J Das and A Dutta, 2012. Effect of certain feeds on growth and survival of Ompok pabo (hamiltonBuchanan) hatchlings in captive condition. Int. J. Sci. Res. Pub., 2: 1-5.

Siddiky MNSM, SBDK Saha, A Ali, MR Washim, 2015. Optimization of stocking density of Mystus gulio. Int. J. Nat. Soc. Sci., 2:60-63.

Siddiqui TQ and MA Khan, 2008. Effects of dietary protein levels on growth, feed utilization, protein retention efficiency and body composition of young Heteropneustes fossilis (Bloch). Fish Physiol. Biochem., 35: 479488.

Tawwab AM, MH Ahmad, YAE Khattab and AME Shalaby, 2010. Effect of dietary protein level, initial body weight, and their interaction on the growth, feed utilization, and physiological alterations of Nile tilapia, Oreochromis niloticus. J. Aquacul., 298: 267-274.

Wahab MA, ZF Ahmed, A Islam and SM Rahmatullah, 1995. Effects of introduction of common carp, Cyprinus carpio on the pond ecology) and growth offish in polyculture. Aquacul. Res., 26: 619-628.

Webster CD, JH Tidwell and D Yancy, 1992. Effect of protein level and feeding frequency on growth and body composition of cage reared channel catfish. Prog. Fish Cult., 54: 92-96.

Wilson RP and JE Halver, 1986. Protein and amino acid requirement of fishes. Ann. Rev. Nutri. 6: 225-244.

Yang SD, C Liou and F Liu, 2002. Effects of dietary protein level on growth performance, carcass composition and ammonia excretion in juvenile silver perch. Bidyanus bidyanus. Aquaculture, 213: 363-372.

Zhang J, L Zhou, X Wang, Q Shao, Z Xu and J Xu, 2010. Dietary protein requirement of juvenile black sea bream, Spurns macrocephalus. J. World Aqua. Soc., 41:151-164. 